\title{
THE COAGULANT ACTION OF RUSSELL VIPER VENOM INVESTIGATED BY THE THROMBOPLASTIN GENERATION TEST
}

\author{
BY \\ G. H. HALL \\ From the R.A.F. Institute of Pathology and Tropical Medicine, Halton, Aylesbury
}

(RECEIVED FOR PUblication AUgUSt 10, 1955)

In the theory of blood coagulation proposed by Biggs (1955) it is supposed that blood thromboplastin is produced by the interaction of antihaemophilic globulin, Christmas factor, platelet lipoid factor, factor VII, factor V, and calcium. Russell viper venom (R.V.V.) can act as a thromboplastin, i.e., convert prothrombin to thrombin, only after combination with platelet lipoid factor and factor V (Rapaport, Aas, and Owren, 1954a). The action of R.V.V. would, therefore, appear to resemble that of a mixture of antihaemophilic globulin, Christmas factor, and factor VII, and the observation of Owren (1954) that R.V.V. gives normal one-stage prothrombin times with samples of plasma deficient in these substances supports this hypothesis. The experiments described in this paper were undertaken to obtain more direct evidence of the relation of R.V.V. to the substances developed during coagulation. The thromboplastin generation test devised by Biggs and Douglas (1953), which enables the contributions of the clotting factors in plasma, in serum, and in platelets to be assessed separately, was used for this purpose. By introducing R.V.V. in place of the ordinary constituents of the test, the relative efficacy of R.V.V. and the thromboplastin antecedents found in the human blood has been determined. In addition, the effect of plasma lipoid on the coagulant action of .R.V.V. (Macfarlane, Trevan, and Attwood, 1941; Fullerton and Anastasopoulos, 1949) and the effect of adsorption of R.V.V. on a mineral precipitate (Jenkins, 1954) have been re-investigated.

\section{Reagents and Methods}

Thromboplastin Generation Test.-The technique of Biggs and Douglas (1953) was adopted.

Russell Viper Venom-Stypven (Burroughs Wellcome and Co.) brand was used throughout. Dilutions were prepared in normal saline.
Blood.-This was obtained from healthy young adults. When blood was required for experiments on the effect of lipoid on thromboplastin generation, venesections were carried out one to one and a half hours after a fatty meal. Plasma and serum were defatted by triple extraction with petroleum ether at room temperature.

Presentation of Results. - The clotting times of the substrate plasma are recorded in the tables. In most cases the clotting times fall to a fairly constant level by the third minute of incubation. The means of these minimal values are calculated and expressed as a percentage of the thromboplastic activity of the control mixture by reference to a thromboplastin dilution curve.

Design of Experiments.-In each experiment the thromboplastic activities of a control mixture containing alumina adsorbed plasma, platelets, and serum, and the activity of R.V.V. alone were determined. In the first experiments one constituent at a time was omitted from the incubation mixtures and replaced by dilutions of R.V.V. and saline. Subsequently, two constituents at a time were replaced by R.V.V. This was done to detect any interaction between R.V.V. and other substances in the mixture producing a substance more active than R.V.V. itself. To determine the effect of blood lipoid on thromboplastin generation the above experiments were repeated using defatted plasma and defatted serum. To discriminate between the ability of R.V.V. to substitute for antihaemophilic globulin and its ability to substitute for factor $V$ when R.V.V. replaced alumina plasma, the thromboplastin generation test was modified by the use of stored plasma as substrate. Finally, the effect of alumina adsorption on the thromboplastic activity of R.V.V. was determined.

\section{Results}

It will be seen from Tables I, II, and III that R.V.V. in dilutions equivalent to those used in prothrombin time estimations $\left(1: 10^{4}-1: 60^{5}\right)$ has but $20 \%$ of the thromboplastic activity of the control mixture of alumina-adsorbed plasma (1:5), platelets, and serum $(1: 10)$. In combination with 
TABLE I

EFFECT OF REPLACEMENT OF ALUMINA PLASMA BY R.V.V.

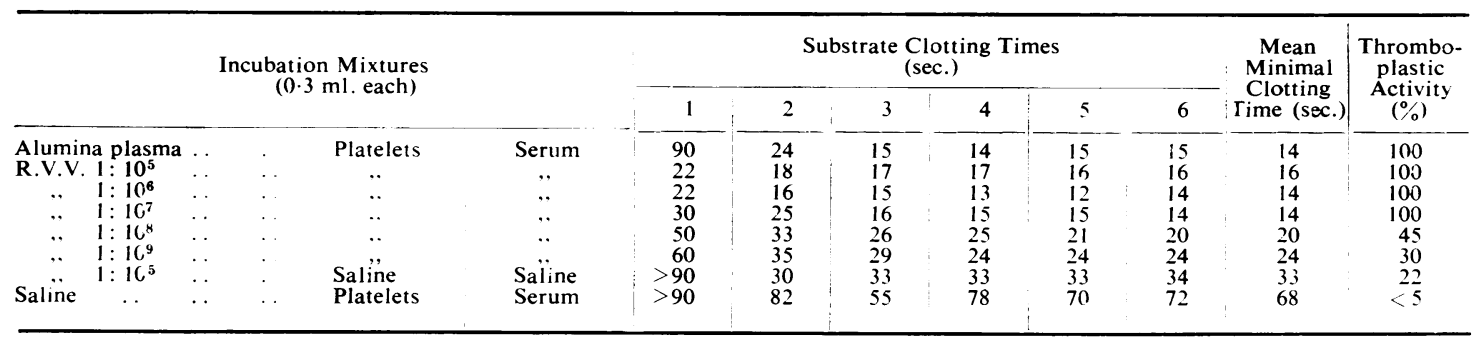

(a) R.V.V. in a dilution of $1: 10^{5}$ has a thromboplastic activity $22 \%$ of the control.

(b) Platelets plus serum have a thromboplastic activity less than $5 \%$ of the control.

(c) R.V.V. in a dilution up to $1: 10^{8}$ in combination with platelets and serum has $100 \%$ activity.

R.V.V. in a dilution of $1: 10^{7}$ is capable of replacing alumina plasma in a dilution of $1: 5$ in the thomboplastin generation test.

TABLE II

EFFECT OF REPLACEMENT OF PLATELETS BY R.V.V.

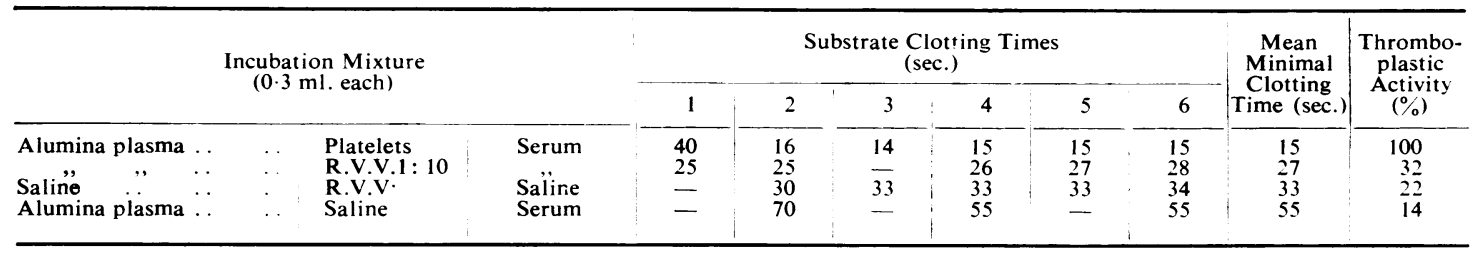

(a) R.V.V. in a dilution of $1: 10^{4}$ has a thromboplastic activity $22 \%$ of the control.

(b) Alumina plasma plus serum has a thromboplastic activity $14 \%$ of normal.

(c) R.V.V. in a dilution of $1: 10^{4}$ in combination with alumina plasma and serum has a thromboplastic activity $32 \%$ of the control.

The effect of mixing alumina plasma with R.V.V. and serum is purely additive. It seems, therefore. that R.V.V. has no significant plateletlike activity.

TABLE III

EFFECT OF REPLACEMENT OF SERUM BY R.V.V.

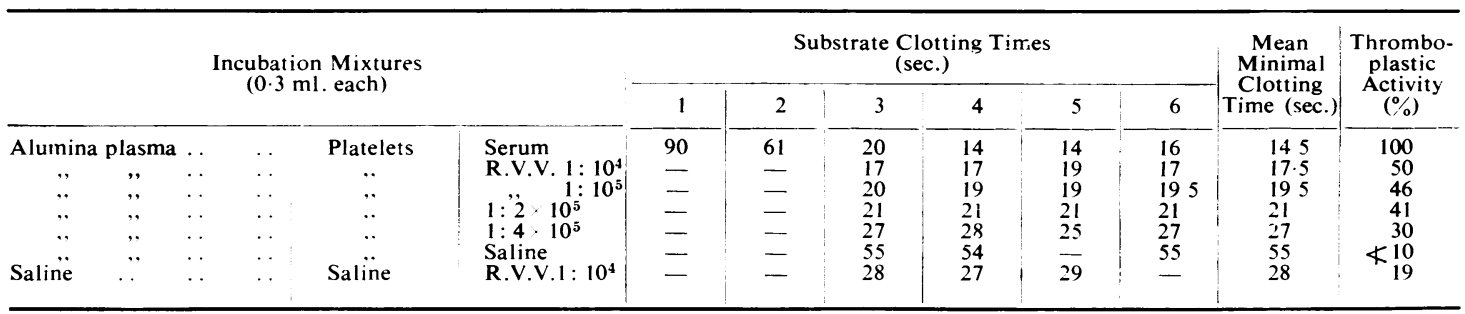

(a) R.V.V. in a diluticn of $1: 10^{4}$ has a thromboplastic activity of $19 \%$ of the control.

(b) Alumina plasma plus platelets has a thromboplastic activity of $10 \%$ of the control.

(c) R.V.V. in a dilution of $1: 10^{4}$ combined with alumina plasma and platelets has a thrombop!astic activity $50 \%$ of the control.

R.V.V. in a dilution of 1 : $10^{4}$ possesses serum-like activity but is less powerful than serum diluted 1 : 10 in generating thromboplastin.

certain of these constituents, however, its potency is greatly enhanced. In a dilution of $1: 10^{7}$ mixed with platelets and serum it proves as effective as a $1: 5$ dilution of alumina plasma (Table I). In combination with alumina plasma and platelets it appears rather less potent $(50 \%$ thromboplastic activity) than a $1: 10$ dilution of serum (Table III) but nevertheless it does have a definite serum-like action. It appears to be quite inert when substituted for platelets (Table II). The various combinations illustrated in Table IV do not modify the basic pattern of these results. Thromboplastin generation by fat-free plasma and serum appears to be normal provided adequate platelets are present. In the absence of platelets, or when R.V.V. replaces platelets, thromboplastin generation is impaired (Table V). No difference between the thromboplastic activities of R.V.V. and alumina plasma was found when either fresh or stored plasma was used as substrate in the test (Table VI). The action of R.V.V. is greatly affected by adsorption on aluminium hydroxide. 
TABLE IV

EFFECT OF REPLACEMENT OF MORE THAN ONE CONSTITUENT AT A TIME BY R.V.V.

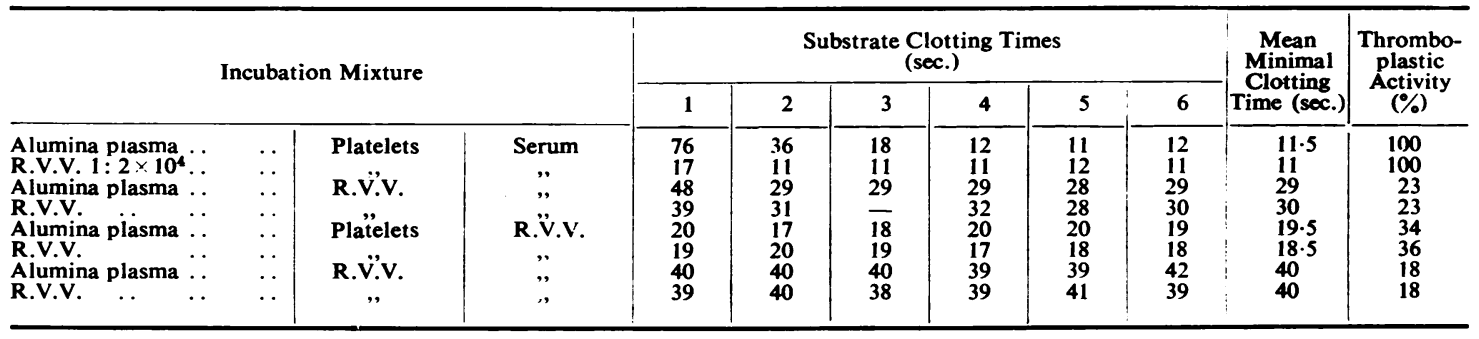

(a) At a dilution of 1:2 $2 \times 10^{5}$ R.V.V. exerts the same effect as 1: 5 alumina plasma, irrespective of the presence of serum and platelets.

(b) The ratio of the amounts of thromboplastin produced in the presence of platelets to the amount produced when platelets are replaced by $R$.V.V. is not reduced by the withdrawal of serum or plasma factors.

(c) The ratio of the amounts of thromboplastin produced in the presence of serum to the amount produced when serum is replaced by R.V.V. is not reduced by the withdrawal of platelet or plasma factors.

TABLE V

EFFECT OF ENDOGENOUS LIPOID ON THROMBOPLASTIN GENERATION WITH AND WITHOUT R.V.V.

\begin{tabular}{|c|c|c|c|c|c|c|c|c|c|c|}
\hline \multicolumn{3}{|c|}{ Incubation Mixture } & \multicolumn{6}{|c|}{$\begin{array}{l}\text { Substrate Clotting Times } \\
\text { (sec.) }\end{array}$} & \multirow{2}{*}{$\begin{array}{c}\text { Mean } \\
\text { Minimal } \\
\text { Clotting } \\
\text { Times(sec.) }\end{array}$} & \multirow{2}{*}{$\begin{array}{c}\text { Thrombo- } \\
\text { - plastin } \\
\text { Activity } \\
(\%)\end{array}$} \\
\hline & & & 1 & 2 & 3 & 4 & 5 & 6 & & \\
\hline $\begin{array}{l}\text { Alumina plasma .. } \\
\text { Defatted alumina plasma } \\
\text { Alumina pläma .. } \\
\text { Defatted alumina plasma } \\
\text { Alumina plasma .. } \\
\text { Defatted alumina plasma }\end{array}$ & $\begin{array}{c}\text { Platelets } \\
\text { ", } \\
\text { R."'.V. } \\
\text {," } \\
\text {," }\end{array}$ & $\begin{array}{l}\text { Serum } \\
\text { Defatted serum } \\
\text { Serum } \\
\text { Defatted serum } \\
\text { Serum } \\
\text { Defatted serum } \\
, ",\end{array}$ & $\begin{array}{l}66 \\
50 \\
50 \\
42 \\
36 \\
47 \\
32 \\
39\end{array}$ & $\begin{array}{l}33 \\
15 \\
16 \\
17 \\
26 \\
36 \\
28 \\
30\end{array}$ & $\begin{array}{r}14 \\
9 \\
10 \\
9 \\
23 \\
32 \\
26 \\
32\end{array}$ & $\begin{array}{r}13 \\
10 \\
9 \\
9 \\
21 \\
33 \\
28 \\
32\end{array}$ & $\begin{array}{r}11 \\
10 \\
9 \\
9 \\
21 \\
36 \\
28 \\
33\end{array}$ & $\begin{array}{l}10 \\
9 \\
10 \\
12 \\
22 \cdot 5 \\
35 \\
30 \\
34\end{array}$ & \begin{tabular}{|r|}
10 \\
9 \\
10 \\
10 \\
22 \\
34 \\
28 \\
33
\end{tabular} & $\begin{array}{l}100 \\
100 \\
100 \\
100 \\
32 \\
21 \\
26 \\
22\end{array}$ \\
\hline
\end{tabular}

(a) Plasma or serum from which the lipoid has been extracted are as potent as ordinary plasma or serum in generating thromboplastin when combined in the usual way with platelets.

(b) When R.V.V. is substituted for platelets the thromboplastic activities of mixtures containing defatted plasma and serum is less than that of mixtures containing ordinary plasma or serum.

In the presence of adequate platelets blood lipoid does not effect thromboplastin generation.

TABLE VI

EFFECT OF USE OF STORED PLASMA AS SUBSTRATE ON SUBSTITUTION OF R.V.V. FOR ALUMINA PLASMA

\begin{tabular}{|c|c|c|c|c|c|c|c|c|c|c|c|}
\hline \multirow{2}{*}{\multicolumn{4}{|c|}{$\begin{array}{l}\text { Incubation Mixture } \\
\text { Fresh Substrate }\end{array}$}} & \multicolumn{6}{|c|}{$\begin{array}{l}\text { Substrate Clotting Time } \\
\text { (sec.) }\end{array}$} & \multirow{3}{*}{ 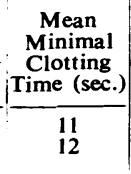 } & \multirow{3}{*}{$\begin{array}{c}\begin{array}{c}\text { Thrombo- } \\
\text { plastic } \\
\text { Activity } \\
(\%)\end{array} \\
100 \\
100\end{array}$} \\
\hline & & & & \multirow{2}{*}{$\begin{array}{c}1 \\
65 \\
16\end{array}$} & \multirow{2}{*}{ 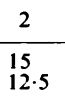 } & \multirow{2}{*}{$\begin{array}{c}3 \\
11 \\
12 \cdot 5\end{array}$} & \multirow{2}{*}{$\frac{4}{(17)}$} & \multirow{2}{*}{$\frac{5}{11 \cdot 5}$} & \multirow{2}{*}{$\frac{6}{125}$} & & \\
\hline $\begin{array}{l}\text { Alumina plasma } \\
\text { R.V.V. } 1: 2 \times 10^{5}\end{array}$ & $\begin{array}{l}\cdots \\
\cdots\end{array}$ & $\begin{array}{c}\text { Platelets } \\
,,\end{array}$ & $\begin{array}{l}\text { Serum } \\
\quad,\end{array}$ & & & & & & & & \\
\hline \multicolumn{12}{|c|}{ Stored Substrate } \\
\hline $\begin{array}{l}\text { Alumina plasma } \\
\text { R.V.V. } 1: 2 \times 10^{5}\end{array}$ & $\begin{array}{l}\cdots \\
\cdots\end{array}$ & $\begin{array}{c}\text { Platelets } \\
\text {, }\end{array}$ & $\begin{array}{c}\text { Serum } \\
,,\end{array}$ & $\begin{array}{l}73 \\
21 \cdot 5\end{array}$ & $\begin{array}{l}23 \\
14\end{array}$ & $\begin{array}{l}125 \\
135\end{array}$ & $\begin{array}{l}125 \\
120\end{array}$ & 135 & 130 & $12 \cdot 5$ & $\begin{array}{l}100 \\
100\end{array}$ \\
\hline
\end{tabular}

Accelerated clotting times using brain thrombopiastin: New substrate, 13 sec. Stored substrate ( 3 weeks at 4 = C.), 22 sec.

No difference between the thromboplastic activities of R.V.V. and alumina plasma is found when either fresh or siored plasma is used as substrate.

The serum-like activity is completely removed and plasma-like activity is reduced by approximately two-thirds (Table VII).

\section{Discussion}

It seems from the experiments that the action of R.V.V. resembles that of certain thromboplastin antecedents rather than that of thromboplastin itself. When used in the thromboplastin genera- tion test R.V.V. is an effective substitute for alumina-adsorbed plasma, is rather less active than serum, and is quite inert when substituted for platelets.

As alumina-adsorbed plasma contains two recognized thromboplastin antecedents, antihaemophilic globulin and factor $\mathrm{V}$, the question arises whether R.V.V. is equivalent to one or other or both substances. Rapaport et al. (1954b) have 
TABLE VII

EFFECT OF ADSORPTION OF R.V.V. ON ALUMINA ON ITS ABILITY TO REPLACE SERUM AND ALUMINA PLASMA

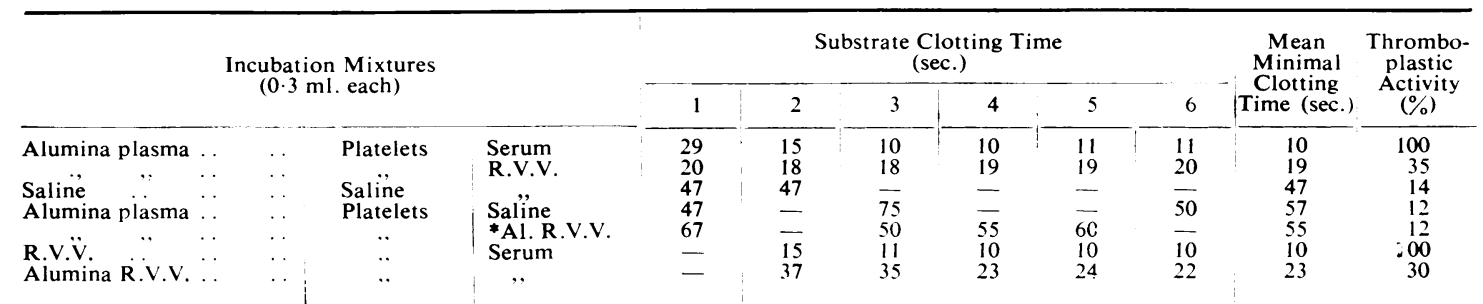

Alumina plasma and R.V.V. adsorbed for three minutes at $37^{\circ} \mathrm{C}$. on aluminium hydroxide. * Alumina adsorbed Russell viper venom (a) When R.V.V. is adsorbed on aluminium hydroxide its thromboplastic activity when substituted for plasma is reduced from $35 \%$ to $12 \%$. This is no more than the activity of alumina plasma plus platelets. The serum-like activity would, therefore, seem to be removed by alumina adsorption.

(b) When R.V.V. is adsorbed on alumina its thromboplastic activity when substituted for alumina plasma is reduced from $100 \%$ to $30 \%$.

found that R.V.V. gives a prolonged prothrombin time with plasma deficient in factor $V$ so it is likely that R.V.V. contains no equivalent to factor V. If this be so, it is difficult to see why R.V.V. is so effective in replacing alumina plasma in the thromboplastin generation test, for when plasma deficient in factor $\mathrm{V}$ is used abnormal resuits are recorded (Biggs and Douglas, 1953). One possible explanation is that the generation of thromboplastin is completed by factor $\mathrm{V}$ in the substrate plasma. However, when stored plasma, presumably deficient in factor $\mathrm{V}$, is used as substrate, no difference was found between the action of alumina plasma and R.V.V. It is possible that the serum provides enough factor $\mathrm{V}$ to complete this reaction. At all events these findings imply either that R.V.V. does in fact contain a factor V equivalent, or that if the thromboplastin generation test is carried out using normal plasma and serum deficiency in factor $\mathrm{V}$ may not be detected, use of the patient's own plasma as substrate and the patient's own serum in the test would be theoretically preferable.

The absence of platelet activity from R.V.V. has been described previously (Biggs and Macfarlane, 1953) and requires no further comment.

Russell viper venom in dilutions similar to those used in prothrombin time estimations fails to replace serum completely in the thromboplastin generation test. This is of interest since it is known that R.V.V. contains a substance similar in action to factor VII (Jenkins, 1954) and that the prothrombin time of plasma deficient in Christmas factor (Owren, 1954) is normal when R.V.V. is used as a source of thromboplastin. These facts suggest that R.V.V. contains equivalents to both factor VII and Christmas factor. The observation that prothrombin times in patients receiving coumarin anticoagulants fail later and more irregularly when R.V.V. is used as a thrombo- plastin than when brain extract is used (Biggs and Macfarlane, 1949) supports this hypothesis. At present factor VII and Christmas factor are the only coagulation factors recognized in serum. Why then is R.V.V. less effective than serum in generating thromboplastin ? One reason for the discrepancy may be that R.V.V. was used in too high a dilution in the test. Another possibility is that the lipoid may be responsible for the superior activity of serum, but the experiments on the action of lipoid make this unlikely. It is also conceivable that serum contains an as yet undefined clotting factor other than factor VII or Christmas factor, which is lacking in R.V.V. Further experiments are being carried out to elucidate the difference between R.V.V. and serum.

Blood lipoid is seen only to effect thromboplastin generation when no platelets are present in the incubation mixtures. In these circumstances the blood lipoid exerts a platelet-like action-an effect first noted by Cramer and Pringle (1913). When R.V.V. is used as a thromboplastin in prothrombin time estimations no special precautions are taken to preserve platelets and the amount of fat in the blood significantly affects the results obtained (Fullerton and Anastasopoulos, 1949). This effect may be suppressed by previously combining R.V.V. with lecithin (Witts and Hobson, 1940). It would seem likely that were precautions taken to preserve the platelets in plasma the effect of lipoid would again be negligible (Hall, 1956).

When R.V.V. is used in generating thromboplastin it will be seen from all tables that the process occurs more quickly than when the usual constituents are employed. This observation, taken together with considerations already discussed, indicates that R.V.V. contains partially prepared thromboplastin, possibly resembling that produced by the interaction of antihaemophilic globulin and Christmas factor (Biggs, 1955). Much of the time 
taken for blood to clot after shedding is occupied by the activation of precursor substances which then react very quickly (Owren, 1954). The speed and efficacy of very small quantities of R.V.V. in causing blood coagulation is possibly due to the fact that it provides an equivalent to an intermediate product which is developed late in the chain of reactions characterizing coagulation. It is not known if the clotting factors which R.V.V. contains are identical with those developed in blood during coagulation. Some evidence was obtained during these experiments that R.V.V. differed from the factors present in alumina plasma in that adsorption on alumina significantly impaired its activity.

\section{Summary}

Russell viper venom (R.V.V.) was substituted for the normal constituents of the thromboplastin generation test. Its action closely resembles that of alumina plasma but it is relatively weaker as a substitute for serum and it has no platelet-like activity. In the presence of platelets blood lipoid does not appear to affect thromboplastin generation.

The relation of R.V.V. to blood thromboplastin antecedents is discussed.

I wish to thank officers and technicians of this laboratory for valuable help in the preparation of this paper.

\section{REFERENCES}

Biggs, R. (1955). Brit. med. Bull., 11, 5

- and Douglas, A.S. (1953). Journal of Clinical Pathology, 6, 23. _ and Macfarlane, R. G. (1949). Ibid., 2, 33.

(1953). Human Blood Coagulation and its Disorders, p. 259. Blackwell, Oxford

Cramer, W.: and Pringle, H. (1913). Quart J. exp. Physiol., 6, 1. Fullerton, H. W., and Anastasopoulos, G. (1949). Brit. med. J., 2, 1492.

Hall, G. H. (1956 Brit. med. J., 2, 207.

Jenkins, J. S. (1954). Journal of Clinical Pathology, 7, 287.

Macfarlane, R. G., Trevan, J. W., and Attwood, A.' M. P. (1941).

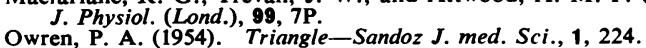

Rapaport, S. I., Aas, K., and Owren, P. A. (1954). Scand. J. clin. Lab. Invest., 6, 82.

Wit - (1954b). Blood, 9, 1185.

Witts, L. J., and Hobson, F. C. J. (1940). Brit. med. J., 2, 863. 